\title{
Do copyright d̀ co-pirataria comunicacional da violência
}

A VIOLÊNCIA SEMPRE CONSTITUIU, para as ciências humanas e sociais, um tema privilegiado de investigação, mesmo que de modo indireto, considerando-se sua obstinação para potencialmente desviar o laço social de seus ideais de perfeição. Esta problemática sempre sofreu com uma concepção binária das coisas, como se a violência fosse exterior a este mesmo elo social, como se este último não se servisse, e mesmo não produzisse, a violência, para cumprir sua intenção de troca, de convivência, de alteridade. Um bom príncipe do positivismo sociológico, mas também apesar das posições que ele teve que sustentar, Emile Durkheim reconhecia, aliás, em matéria de religiosidade e de sagrado, por exemplo, o papel assumido por esta violência no universo coletivo do acesso ao Outro, ou aos outros. A alteridade, e é disso que se trata primordialmente, evoca, com efeito, o encontro das diferenças, mas também sua possível alteração.

Aplicada à comunicação, a tudo o que esta nebulosa terminológica pode necessariamente encobrir, a violência é também considerada como um objeto de perversão ou de desvio do elo social. Por que teria ela o direito de ser tratada pela mídia, já que sua visualização ou sua apresentação pode gerar perturbações entre aqueles que a recepcionam? Derivações que se traduziriam então em violência exponencial. Como veremos, o espectro da contaminação e do sobrelanço reveste esta concepção, ela própria ofuscada pela suficiência da sua unilateralidade em matéria de mensagem informativa. Existe aí um pressuposto que se quer resolutamente científico, mas cuja lógica monovalente apóia-se, em gran-

\section{PhilippeJoron*} de parte, sobre uma compreensão normatiIRSA-CRI / Montpellier III 
aos efeitos exclusivamente anômicos desta mesma violência, a fortiori quando estes aplicam-se aos usuários dos meios modernos de comunicação: uma violência que só pode subverter o elo social, rasgar a relação com outro, aniquilar toda possibilidade de humanidade recíproca. Afirmar isso é rapidamente esquecer que ela constitui um dos mais antigos vetores de troca, tanto que ela foi historicamente instrumentalizada enquanto objeto de aliança.

Segundo sua etimologia latina, a violentia significa o uso da força. $\mathrm{O}$ verbo viola$r e$ indica uma referência à transgressão, à profanação, ao uso de vias proibidas. Comunicar pela violência ou resolver a troca na possibilidade de um aniquilamento: isso supõe forçar o dédalo da alteridade e da diferença. Um forçamento individual ou coletivo, físico ou psicológico, natural ou cultural, justificado ou não, cuja prática permite expressar um estado, satisfazer uma necessidade imediata, mudar uma situação julgada intolerável, ou manter e controlar arranjos percebidos como satisfatórios. A violência desdobra-se como um vetor de comunicação social, uma linguagem ou uma metalinguagem que explora um cuidado ou uma negação de si jogada sobre os outros.

Se todo grupo social é redutível ao fato de comunicar, esta equação é ainda mais flagrante nas sociedades ditas modernas, tecnicamente organizadas, onde os termos comunicação e imagem qualificam de modo exemplar um novo embaralhamento mundano e social. O que denominamos "sociedade da comunicação" ou ainda "sociedade da imagem", mesmo se essas duas acepções remetem a disposições organizacionais diferentes, é estreitamente ligado ao desenvolvimento das técnicas e, por conseguinte, ao tratamento midiático da relação com o outro, com o mundo e consigo mesmo. $\mathrm{O}$ avento da reprodução fotográfica e fonográfica, do cinematógrafo, da comunicação à distância e das indústrias que cooptaram estas inovações modificou consideravelmente a definição da nossa identi- dade. O fato de se ver ou de se ouvir em gravações (reprodução analógica e digital), de se representar o outro - ao vivo ou não -, sem barreiras espaciais e temporais, ou ainda de viver a interpenetração do real e do virtual, do universo online e do mundo offline, tudo isso induz necessariamente mudanças das mentalidades e dos comportamentos que estruturam a conformação dinâmica das nossas sociedades. Nesta perspectiva, a história moderna da mídia se apresenta também como uma tentativa polimorfa de reinvestimento do laço social, por meios apropriados, que permite a resolução pontual do dilema entre o isolamento do indivíduo e sua tendência à exteriorização e à reliance social.

"Comunicações da violência" ou "violências da comunicação" não vêm a ser a mesma coisa ? Sem dúvida, se identificarmos um conteúdo informativo com sua transmissão, particularmente quando a difusão de uma cena de violência é encarada como um ato de violência total. Mas o oceano corrosivo desse amálgama, que contém inevitavelmente uma parte de verdade, não poderia, no entanto, dissolver os continentes movediços de uma tal problemática. Dito de outra maneira, existe também uma violência na sua não divulgação, tanto quanto existe ainda uma violência na assepsia alienante de certas políticas comunicacionais, como existe, enfim, uma violência também presente em propósitos ou imagens que não pertencem a seu registro. Do mesmo modo, o fato de lhe dar um rosto, de nomeá-la, de abraçá-la midiaticamente, viria então a produzi-la novamente, sobretudo a reproduzi-la por redundância diferencial, e não apenas mimética. Passaríamos então do copyright da violência à sua co-pirataria comunicacional, de um ato de violência inicial à produção coletiva de cópias transformadas, liberadas do original pela multiplicidade de perspectivas, pelas repetições focais que desgastam o objeto, mas que o diferenciam ao mesmo tempo. A consideração dessas dimensões leva à evocação de um princípio de incerteza que ten- 
de a atrapalhar algumas das proposições funcionalistas que povoam as ciências da comunicação.

Refletida a partir do consumo de massa e de seus imperativos político-econômicos, a comunicação é muitas vezes percebida como confortavelmente presa a um princípio informativo que orientaria a produção, a transmissão e a recepção de uma mensagem utilitária. À primeira vista, parece evidente que a circulação das informações entre emissores e receptores, por meio de transmissores profissionais, transforma de maneira contínua o estoque de conhecimentos de que dispõem os atores sociais para apreender o seu mundo. Mas esta modificação constante dos conhecimentos acessíveis no mercado da informação, tanto em termos quantitativos quanto qualitativos, não é apenas imputável ao emissor, nem mesmo ao transmissor. É preciso ainda que eles sejam validados, digeridos e reelaborados pelo agente receptor. Este não se define por uma suposta passividade ou indolência frente às informações recebidas, mas ao contrário por uma mistura complexa de aceitações, refutações, escolhas e articulações. Ele faz um balanço, filtra as mensagens, forja uma opinião, elabora estratégias, implícitas ou não, de assimilação e de retransmissão que certamente têm uma incidência sobre o produtor e o propagador da mensagem original. A comunicação e a difusão das informações, dessa forma, seriam apreendidas segundo um eixo unilateral, mas antes como um esquema parasitado e parasitário de circularidade, englobando perdas e ganhos de significações.

Ao prisma de suas dessemelhanças, as análises que seguem levam a considerar esta estranheza da violência em estado de comunicação, examinando assim os pontos de junção, as linhas de fratura e os lugares de rompimento com que ela preenche o laço social. Todas as contribuições propostas aqui remetem-se ao campo plural das sociologias do imaginário e do cotidiano ou, se preferimos, a uma heurística do elo social que acompanha as produções imaginárias na escrita partilhada de uma cotidianidade soberana. Segundo esta perspectiva, Jean-Bruno Renard enfatiza a dimensão trágica e violenta desta mais antiga mídia do mundo, que é o rumor. Ele a examina segundo três registros de propagação e de deformação: as informações amotinadoras, as elucubrações criminais e as lendas urbanas. Patrick Tacussel se empenha em avaliar a pregnância do imaginário social (do inconsciente coletivo à memória partilhada) quanto à morte midiatizada, entre faits divers e acontecimentos, estudando a "ressonância emocional" da sua repetição no cotidiano. Michel Moatti desvenda os subterrâneos do mundo virtual, os esconderijos macabros da undernet, que abrigam imagens e discursos sórdidos, os quais oscilam entre visibilidade e segredo. Dominique Crozat questiona a hiper-realidade dos espaços sociais, mostrando o seu grau de afetação, pela banalização midiática de uma espacialidade metaforizada, sobre a produção do social na sua concretude. Denis Fleurdorge analisa a violência política, na sua dimensão transhistórica, como uma alteridade de transferência incompressível que se desdobra no corpo social a partir de duas formas de expressão: a emoção e a racionalidade. Michel Crespy investiga os arcanos da comunicação referente à guerra, escavando os princípios maiores do controle da informação e da manipulação pela imagem em situações de conflitos internacionais. Jean-Paul Laurens examina o tratamento midiático da violência escolar na França, o qual tende a concentrar-se sobre fatos de excepcional gravidade, assim como de origem estritamente exógena à instituição educativa. Martine Xiberras interroga os paradoxos axiológicos nos quais a mídia moderna mergulha, que confrontam a tradição iconoclasta da civilização que os mantém aos derramamentos convulsivos de uma imagem que procura se liberar do seu próprio recalcamento. Hélène Houdayer mostra como as noções de aventura, de embriaguez e de potência, enquan- 
to eixos referentes de condutas de adicção, são amplamente disseminadas na linguagem publicitária para estimular as compulsões de compra e de uso aplicadas aos produtos de consumo. Emmanuel Gleyze dá conta de uma pesquisa de campo concernente às representações da violência entre os trabalhadores sociais, assim como as estratégias elaboradas por estes durante situações de crise para assegurar, ao mesmo tempo, sua própria coesão profissional e a continuidade das relações com os usuários. A partir de exemplos tirados da atualidade norte-americana, Olivier Cathus analisa a interiorização dos preconceitos e estereótipos relativos aos negros, cujas culturas determinam entretanto, no mercado midiático e econômico mundial, modos de ser e de pensar fortemente sacralizados pela juventude.

Agradeço a todos os autores que participaram da elaboração desse dossiê. Pertencendo na sua maior parte ao IRSA-CRI ${ }^{1}$ de Montpellier III, eles procuraram abordar a problemática proposta utilizando seus respectivos objetos de pesquisa como alavanca de desvendamento. Agradeço igualmente aos principais atores do Programa de Pós-Graduação em Comunicação Social da Pontifícia Universidade Católica do Rio Grande do Sul, assim como aos responsáveis pela Revista FAMECOS, em particular a Juremir Machado da Silva e Francisco Menezes Martins, que, no quadro de um acordo de cooperação unindo nossas Universidades e Centros de Pesquisa respectivos, favoreceram plenamente a realização deste projeto. É neste mesmo espírito de transdisciplinaridade, mas também de interculturalidade que uma próxima publicação dos Cahiers de l'IRSA dará continuidade, na França, a este questionamento sobre o entrelaçamento da violência e da comunicação, graças aos reforços entusiasmados de pesquisadores brasileiros especializados em sociologia da cultura. Pretexto, dirão uns; sorte, alegarão outros, para que o encontro dos espíritos e das ações pudesse dar sentido ao desejo de estar junto, entre o aqui e o alhures, de cada uma das nossas buscas. Agradeço ainda à Universidade Montpellier III, a seu serviço de relações internacionais, e particularmente a Francis Uteza, professor de literatura e cultura lusófona, cujos conselhos pertinentes em matéria de cooperação franco-brasileira facilitaram a concretização dos laços que unem doravante nossas duas instituições. Agradeço enfim à Clélia Pinto que, com paciência e perspicácia, traduziu em língua portuguesa as diversas sensibilidades estilísticas deste dossiê. Sem ela, sem a dor e o prazer que ela manifestou no desafio, este ensaio de intertextualidade universitária não teria provavelmente sido concluído de acordo com os critérios e limites que havíamos definido .

\section{Notas}

* Professor de Sociologia na Universidade Paul Valéry Montpellier III. Coordenador da Graduação de Sociologia. Doutor em Sociologia pela Universidade Paris V Sorbonne. Pesquisador no Institut de Recherches Sociologiques \& Anthropologiques et no Centre de Recherches sur l'Imaginaire (IRSA-CRI). Contato: philippe.joron@univ-montp3.fr

1 Institut de Recherches Sociologiques \& Anthropologique - Centre de Recherches sur l'Imaginaire. 